\title{
Strategic Planning for the Sustainable Development
} of Territories

\footnotetext{
Submitted 11/04/20, 1 st revision 10/05/20, 2nd revision 23/06/20, accepted 15/08/20

Denys L. Tarasenko ${ }^{1}$, Olena B. Tsyklauri ${ }^{2}$, Svitlana I. Belei ${ }^{3}$, Maryna O. Riabenka ${ }^{4}$, Iryna O. Mazurkevych ${ }^{5}$

Abstract:

Purpose: The main purpose of this article is to determine the features of the application of strategic planning to ensure sustainable development of territories.

Design/Methodology/Approach: The study is based on statistics from international institutions such as the European Regional Development Fund, Eurostat, The World Bank, the Institute of Regional Development, as well as theoretical and practical developments of foreign scholars.
}

Findings: The results of the study show that ensuring the sustainable development of territories is an important sphere for ensuring the sustainable development of countries in general. At the same time, one of the key stages of ensuring their sustainable development is the stage of long-term navigation, which determines the further guidelines and measures the need to be implemented.

Practical Implications: This study raises awareness of the components of the strategic planning process, the directions of its implementation, the pace of economic development of individual territories in European countries, as well as revealing the features of sustainable development of territories on the example of one country.

Originality/Value: The study emphasizes that the existing development potential of the territories at the period of studying of this issue is not fully disclosed. Programs that are implemented have a long period of their implementation, which ultimately affects the effectiveness of this process. So, it can be a kind of milestone for further strategic planning of territorial development, as the deadline for most regional development programs ends this year.

Keywords: Strategic planning, territories, strategy, GDP, employment of population, European Regional Development Fund, program of territories' development.

JEL Classification: A11, A14, B4.

Article Type: Research paper.

${ }^{1}$ Professor, Donetsk State University of Management, Mariupol, Ukraine,

E-mail: tarasenkodenis81@gmail.com

${ }^{2}$ Senior Lecturer, Donetsk State University of Management, Mariupol, Ukraine, E-mail: o.tsyklauri@gmail.com

${ }^{3}$ Associate Professor, Yuriy Fedkovych Chernivtsi National University, Chernivtsi, Ukraine, E-mail: s.belei@chnu.edu.ua

${ }^{4}$ Associate Professor, Vinnytsia Institute of Trade and Economics of Kyiv National University of Trade and Economics, Vinnytsia, Ukraine, E-mail: marishkaryabenka@gmail.com

${ }^{5}$ Associate Professor, Vinnytsia Institute of Trade and Economics of Kyiv National University of Trade and Economics, Vinnytsia, Ukraine, E-mail: Mazurkevich78@ukr.net 


\section{Introduction}

Within the conditions of the significant spreading of territories' integration processes, considerable changes in approaches to their management are provoked. Along with this, the level of complexity of territories' management is increasing, which relates to the acquisition of a greater level of independence and the presence of facts of delegation of authority to organize their social-economic development. The processes incurred put forward requirements for the formation of specific methods of managing the activities and development of territories that would be comparable not only with its new status, but also with changing conditions of external environment. As a result, the new status of the territories influences the need to apply strategic management and planning methods, which can be used to achieve the function of the strategic vision of a territory's development or their combination.

Therefore, currently, issues related to strategic planning for the development of territories are increasingly becoming the center of concentration of numerous scientists, economists, and politicians. This emphasizes the importance of strategic planning in the process of managing the development of the national economy of the world countries and their territories.

\section{Literature Review}

Along with the foregoing, an analysis of the existing achievements of scientists regarding strategic planning for corporate development, in general, as well as strategic planning for the development of territories, in particular, has become widespread. Thus, for instance, the scholars Plaziak and Rachwal (2014), investigating the features of strategic planning at the company level, have noted that it is a process of documenting and determining the direction of your business by assessing where we are now and what we want to achieve in the future. The strategic plan, developed during this process, makes it possible to accumulate our mission, vision, and values within one document, as well as long-term goals and action plans that we will use to achieve them.

At the same time, the scholars Albrechts et al. (2017), in their research at the end of the last century, has noted that the development of a strategic plan should take into account the use of public control mechanisms to achieve the goals set by the development strategy of a particular territory. In addition, the list of specific tools for management of local development includes economic, legal, and motivational mechanisms. Their combined application is aimed at ensuring progressive economic development of territories.

Scientists of the Corporative Finance Institute Brocks and Schulitz (2006) consider strategic planning from the perspective of representing it as the art of formulating business strategies, their implementation and the ultimate assessment of their impact based on organizational goals. In addition, strategic planning focuses on the 
integration of various business departments, including accounting and finance, research and development, production, marketing, information systems, management, etc., in order to ensure the achievement of certain organizational goals (Brocks and Schulitz, 2006).

On the other hand, Arabadzhyiev et al. (2020) considering this concept, have noted that strategic planning is increasing frequently carried out at the city and regional levels as a tool to address economic, social, and environmental issues.

In the research article by Jerzy et al. (2019), it has been noted that it is necessary to develop a policy to stimulate the formation of a strong middle class in the territories for successful development of the territories. Along with this, the development of the middle class is possible only, if the economic standard of living of the population is improved, which in turn requires the elimination of interregional imbalances, ensuring sustainable economic growth of territories and increasing their level of competitiveness by developing and implementing effective public policy in the territories, aimed at creating favorable conditions for their economic growth and integral use of their economic potential (Jerzy et al., 2019). The development of an effective policy, in turn, requires careful strategic planning, confirming its importance.

At the same time, the President of the Mazovia Region Struzik (Teixeira and Boda, 2019), during the 136th plenary session of European Committee of the Regions pointed out that strategic planning of territories is the starting point for successful development. Long-term regional strategies should ensure the sustainable development of territories. Herewith, during their development it is necessary to use qualitatively prepared analysis and clearly and professionally defined long-term goals (Petrunenko et al., 2020).

In a scientific article by Karpenko (2016) it has been noted that strategic planning acts as an integrating force that organizes and coordinates the process of identifying strategic goals and forms the basis for further allocation of resources at the level of regional authorities. In addition, strategic planning focuses on the issues of socialeconomic development of territories, as well as it provides a basis for the formation of interaction between managers and individual employees in the process of creating and implementing a strategy for development of territories (Karpenko, 2016).

The importance of the integration and cooperation of territories for sustainable development is discussed by many scholars Arabadzhyiev et al. (2020) in addition, some of them emphasize the importance of communication between communities Romanenko (2016). Also, in the promotion of sustainable development is important to provide financial support for the process of creating economic, social, and environmental incentives (Albrechts et al., 2017). 
At the same time, Klymenko et al. (2016) has conducted the research on existing approaches to the organization of strategic planning, noting that the method of developing a strategic plan's development depends on the nature of leadership, culture of the planning object, the complexity of its environment, the size of the object, etc., and the scholar has noted that nowadays it is difficult to find entities that would neglect the benefits of using strategic planning in their activities. Along with this, the process of its implementation should necessarily include the stage of viewing, clarifying, and creating the mission of the organization based on the needs of interested parties (Blakely, 1994).

The elaboration of strategies for the development of agro-industrial complex, adjusted to the capabilities of each territory is an extremely important direction among the possible areas of strategic planning, according to Metaxas (2002), for as much as the powerful agricultural sector of the economy is the key to ensuring industrial safety for the country.

\section{Research Methodology}

The methodological basis of the study consists of the works of foreign and domestic researchers, official statistics, reports, based on which conclusions are formed on the state of development of territories in the context of European countries. Methods of analysis, synthesis, formalization, logical abstraction, theoretical learning, monographic, systematization and classification, abstract-logical and others have been used. Data from The World Bank (2020), Eurostat (2020a; 2020b), European Regional Development Fund (Interreg Europe, n.d.), Institute of Regional Development have been used to assess the level of development of countries in the regional context, as well as to analyze existing programs and strategies for development of territories.

\section{Empirical Findings}

The expansion of cross-border cooperation, along with the strengthening of international ties between the countries, have prompted the emphasis on inequality in their development, including territories. Therefore, there is a need to find possible ways to equalize the existing disparities on the way to sustainable development of territories and the development of the state as a whole system in general. Long-term planning, which in other words is called strategic planning is one of the tools that can be used for these purposes.

According to a study conducted by Brocks and Schulitz (2006) the need for strategic planning in the context of territories is becoming increasingly important due to the growing relevance of the territory in the structure of sustainable social, economic, political and environmental development (Bashtannyk et al., 2020). This, in the aggregate, has entailed the need to determine the nature and features of strategic planning of territories in terms of individual countries, with the identification of 
those, where a successful practice of its implementation has been revealed. In addition, these researchers have also indicated that the use of strategic planning for development of territories is an effective and efficient tool, by which the principle of fairness in the allocation and use of available resources can be implemented. At the same time, considering the level of strategic planning - that is, territorial, this process acquires extremely complex features, because it involves consideration of an extremely large number of factors and nuances. Consequently, we propose to consider a schematic representation of the strategic planning of territories' development by using Figure 1.

Figure 1. Components of the strategic planning process

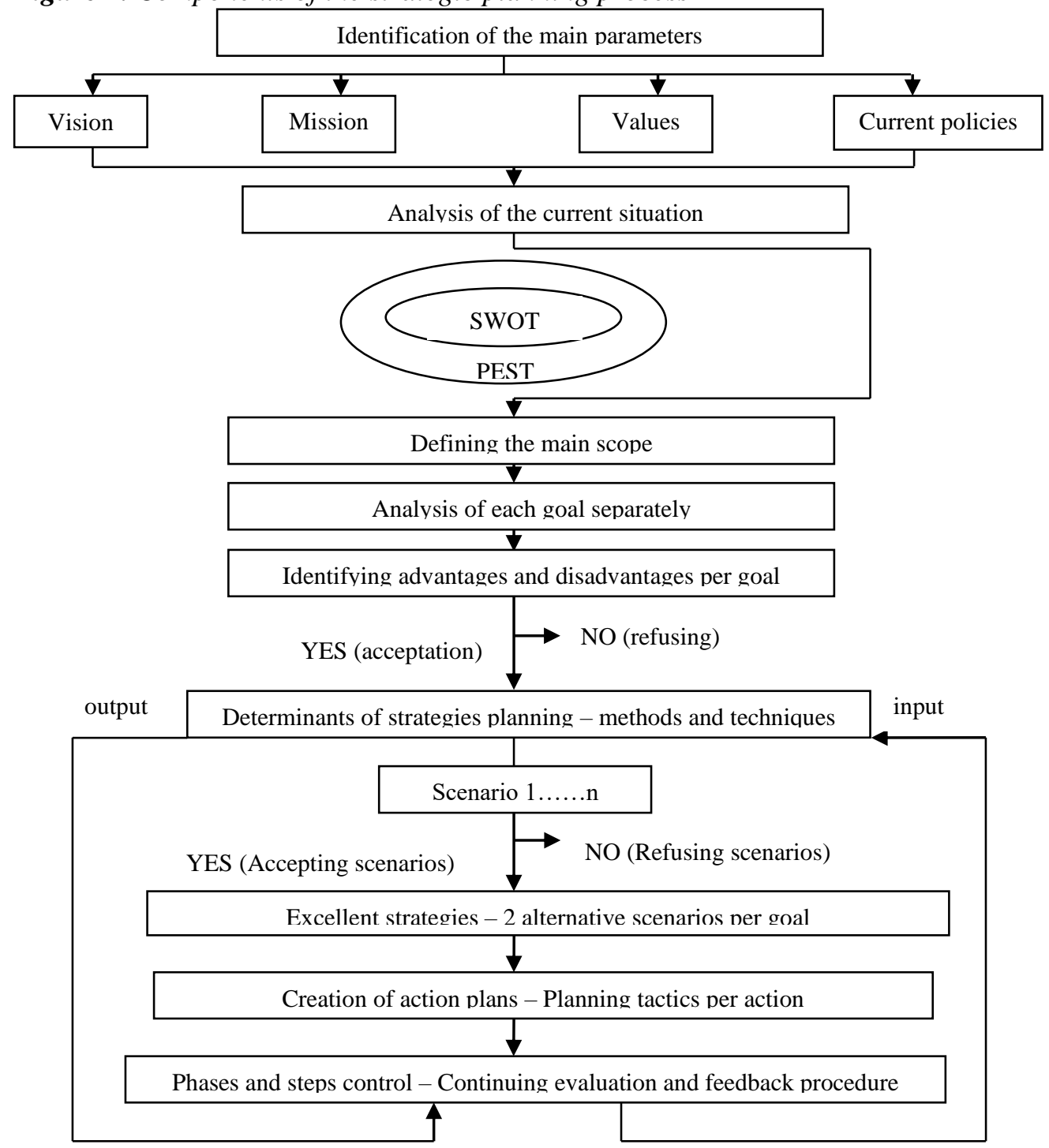

Source: Created by the authors on McCarty (2020). 
Thus, it can be seen from Figure 1 that the strategic planning process begins with the identification of key parameters, namely, mission, vision, assessment and current policy. In addition, the current situation is analyzed by using SWOT or PEST analysis. This phase goes into the stage of determining the scope of the strategy, analysis of each of the proposed goals for the development of the territory, which after the adoption of the appropriate direction of the goals' implementation follows in the choice of specific tools and methods to achieve them.

Thus, the development of several scenarios of further actions for achievement of the certain purposes takes place, with a choice of two best ones. After this, the formation of tactical action plans takes place, with subsequent step-by-step control and the introduction of appropriate changes, depending on changes in the conditions of the external and internal environment of the territory.

At the same time, it should be noted that there are different areas of strategic planning in the regional context, depending on the scope of their direction. In particular, let us consider them in more detail by using Figure 2.

Figure 2. Directions of strategic planning in the context of territories

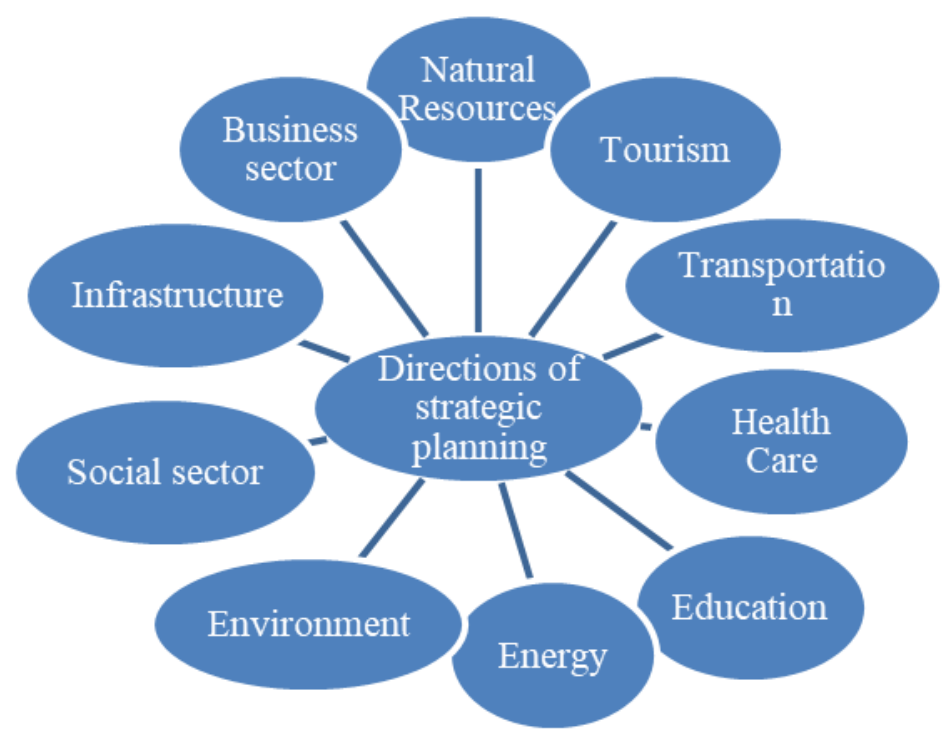

Source: Created by the authors on Teixeira and Boda (2019).

Thus, from the above Figure, we can conclude that strategic planning can focus on the development of such areas as tourism, transportation, health care, education, natural resources, business sector, infrastructure, social sector, and environment. 
Along with this, the Karpenko (2016) notes that the developed strategic plan is a key element of strategic planning, it is a particular end product of this process. In this case, this document should reflect the Vision Statement. The Vision Statement is a way of presenting the goals we plan to achieve as a result. This element of the strategic plan is especially actively used by representatives of the business environment. For instance, the well-known Harion-Davidson's Vision Statement focuses on keeping its brand world-renowned and valuable, using the efforts of all interested parties, while stimulating the growth of innovation.

The Mission Statement is the next element of the strategic plan. Although, these two elements of the strategic plan are remarkably similar and intertwined, the Mission Statement describes what we are doing now, while you look through the prism of your activity at interested parties. Herewith, these two elements within the strategic plan may not be separated and presented in one section.

In addition, this document should contain Core Values, describing our core beliefs and behaviors, which ultimately make it possible to achieve our vision and mission. Along with this, within the framework of the strategic plan, the data of the SWOT analysis are presented and the long-term goals that need to be achieved within the framework of this territory are revealed. Each long-term goal should be divided into several tactical ones that will help achieve it. At the same time, each goal should be as smart as possible; concrete, measurable, achievable, realistic and time-based. Therefore, after the development of goals within a year, they are divided into actions and tasks for the next three months, and so on. In other words, short-term goals are a kind of action plan, which is extremely important when elaborating a strategic plan for the development of the territory, because this process involves an extremely large number of resources, both human and financial ones. Thus, the more this process is divided into specific measures, the higher its efficiency will be. The presentation of a step-by-step action plan for all participants in strategic planning is the final element of this document.

In the structure of the territory, various institutions and establishments are responsible for conducting strategic planning and development, depending on the direction of its implementation. For example, the relevant ministry or relevant institution, depending on the country of implementation, will be responsible for conducting strategic health care development planning in the territory.

At the same time, at European level, the Institute of regional development is the supreme body responsible for the development of territories; its basic activity centers around promoting the development of European territories, the international exchanging of know-how and experience and the formation of key players in various spheres (Eurostat, 2020a). 
At the same time, at the stage of preparation for strategic planning it is important to consider the initial conditions, which will be the basis for the development. The statistics, from national and international sources will be the basis for this.

The Eurostat (2019) regional yearbook occupies an important place among the international sources of statistical data on the situation in the territories. This document contains information on the key activities of the territories, in terms of components, which have been reflected in Figure 2. The last publication was published in June 2019.

Therefore, from the Eurostat (2019) regional yearbook we obtain data on the level of territories' GDP in European Union for 2018, the analysis of which further will make it possible to draw conclusions about the pace of development of territories within a number of European countries. Let us draw up results of research by means of Table 1.

Table 1. Territories' GDP in European Union, 2018

\begin{tabular}{|l|l|l|l|l|}
\hline Territories & $\begin{array}{l}\text { GDP } \\
\text { (€ mil) }\end{array}$ & $\begin{array}{l}\text { Share in EU-27 } \\
\text { / national GDP }\end{array}$ & $\begin{array}{l}\text { GDP per } \\
\text { capita, }(\boldsymbol{\epsilon})\end{array}$ & $\begin{array}{l}\text { GDP per } \\
\text { person } \\
\text { employed, } \\
\text { PPS, } \\
\text { 27EU=100) }\end{array}$ \\
\hline Belgium: & 459820 & $\mathbf{3 . 4}$ & $\mathbf{4 0 2 0 0}$ & $\mathbf{1 2 9}$ \\
Brussels Region & 83987 & 18.3 & 69400 & 161 \\
Vlaams Gewest & 269886 & 58.7 & 41000 & 129 \\
Région Wallonne & 105695 & 23.0 & 29000 & 112 \\
\hline Germany: & $\mathbf{3 3 4 4 3 7 0}$ & $\mathbf{2 4 . 8}$ & $\mathbf{4 0 3 0 0}$ & $\mathbf{1 0 5}$ \\
Baden-Württemberg & 504276 & 15.1 & 45700 & 112 \\
Bayern & 617146 & 18.5 & 47300 & 114 \\
Berlin & 145698 & 4.4 & 40100 & 102 \\
Hamburg & 119046 & 3.6 & 64800 & 132 \\
Hessen & 289044 & 8.6 & 46200 & 116 \\
\hline Greece: & $\mathbf{1 8 4 7 1 4}$ & $\mathbf{1 . 0}$ & $\mathbf{1 7 2 0 0}$ & $\mathbf{8 1}$ \\
Voreia Ellada & 40764 & 22.1 & 13300 & 68 \\
Kentriki Ellada & 38249 & 20.7 & 14100 & 69 \\
Attiki & 87378 & 47.3 & 23300 & 99 \\
\hline Spain: & $\mathbf{1 2 0 2 1 9 3}$ & $\mathbf{8 . 9}$ & $\mathbf{2 5 7 0 0}$ & $\mathbf{1 0 0}$ \\
Noreste & 138003 & 11.5 & 31000 & 109 \\
Comunidad & 230795 & 19.2 & 35000 & 111 \\
Madrid & 195358 & 16.3 & 19400 & 88 \\
Sur & 372202 & 31.0 & 27300 & 102 \\
Este & & & & \\
\hline France: & $\mathbf{2 3 5 3 0 9 0}$ & $\mathbf{1 7 . 5}$ & $\mathbf{3 5 0 0 0}$ & $\mathbf{1 1 5}$ \\
Île de France & 733875 & 31.2 & 59700 & 158 \\
Auvergne-Rhône- & 269964 & 11.5 & 30200 & 109 \\
Alpes & & & 29000 & 102 \\
Languedoc- & 171197 & 7.3 & & \\
\hline
\end{tabular}




\begin{tabular}{|c|c|c|c|c|}
\hline \multicolumn{5}{|l|}{$\begin{array}{l}\text { Roussillon-Midi- } \\
\text { Pyrénées }\end{array}$} \\
\hline Italy: & 1765421 & 13.1 & 29200 & 106 \\
\hline Nord Ovest & 580257 & 32.9 & 36100 & 119 \\
\hline Nord Est & 407852 & 23.1 & 35000 & 112 \\
\hline Centro (IT) & 380858 & 21.6 & 31700 & 107 \\
\hline The Netherlands: & 774039 & 5.7 & 44900 & 110 \\
\hline West-Nederland & 415845 & 53.7 & 50600 & 121 \\
\hline Zuid-Nederland & 160593 & 20.7 & 44000 & 105 \\
\hline Oost-Nederland & 135495 & 17.5 & 37300 & 96 \\
\hline Poland: & 496361 & 3.7 & 12900 & 77 \\
\hline Makroregion & 101425 & 20.4 & 12800 & 78 \\
\hline Południowy & & & & \\
\hline Makroregion & 77679 & 15.6 & 12500 & 73 \\
\hline Północno-Zachodni & & & & \\
\hline Makroregion & 112198 & 22.6 & 20800 & 111 \\
\hline $\begin{array}{l}\text { Województwo } \\
\text { Mazowieckie }\end{array}$ & & & & \\
\hline Sweden: & 471208 & 3.5 & 46300 & 112 \\
\hline Östra Sverige & 214105 & 45.4 & 53200 & 122 \\
\hline Södra Sverige & 186755 & 39.6 & 42400 & 105 \\
\hline Norra Sverige & 70245 & 14.9 & 40100 & 104 \\
\hline
\end{tabular}

Source: Drawn up by the authors on the basis of Interreg Europe (n.d.)

Thus, according to the data, presented in Table 1 we can see that there are territories in the structure of the analysis of the GDP of each country, which in turn can be divided into subregions, as in the case in Germany, Belgium, Greece, Spain, Poland, Sweden, etc. The allocation of the sub-regional level does not take place when the country is small in size or when the territory in its structure is not large, for example, Croatia, some regions of Portugal, Cyprus, Latvia, etc. (Interreg Europe, n.d.).

Thus, according to the information presented in the table, the largest GDP is observed in such countries, as: Germany (334437 million EUR), France (2353090 million EUR) and Italy (1765421 million EUR). In the structure of European GDP, the gross product of these countries is $24,8 \%$; $17,5 \%$; and $13,1 \%$, respectively. At the same time, the lion's share of GDP produced falls at 2 regions in Germany, namely Baden-Württemberg $(15,1 \%)$ and Bayern $(18,5 \%)$. As for France, the key territory to ensure the country's GDP is the territory of Île de France, which produces $31,2 \%$ of GDP. At the same time, Italy's GDP is proportionally produced by the three territories listed in the Table.

However, while the GDP growth rates of these countries have always been high, Poland has only in recent years begun to show high growth rates. This fact is confirmed by the conclusion of the representatives of The World Bank; they indicate that prior the coronaviral infection influenced the world economy Poland had had one of the fastest growing economies in European Union. Thus, the level of household consumption, caused by increased budget expenditures, a tough labor 
market and rising wages, continued to grow (Plaziak and Rachwal, 2014). From the data specified in Table 1 , it can be seen that 3 territories play a key role in the structure of the country's GDP. At the same time, in order to maintain a stable trend of economic growth, it is necessary to focus on strategic development planning of other territories, namely Makroregion Południowo-Zachodni, Makroregion Centralny, Makroregion Wschodni, Makroregion Północny, whose share in the country's GDP is much smaller.

However, at the same time, the main medium-term challenge for sustainable growth is the possibility of strengthening labor supply, under the influence of trends in the global and domestic environment. Consequently, let us analyze the unemployment rate in Poland on the basis of Eurostat data, reflecting it in the dynamics by using Table 2.

Table 2. Territories' employment in Poland, 2018

\begin{tabular}{|l|l|l|l|l|l|}
\hline Territory & $\begin{array}{l}\text { Employment } \\
(\mathbf{1 0 0 0} \\
\text { persons) }\end{array}$ & $\begin{array}{l}\text { Change in } \\
\mathbf{1 0 0 0} \text { persons } \\
\mathbf{( 2 0 1 8 / 2 0 1 7 )}\end{array}$ & $\begin{array}{l}\text { Change in } \\
\text { \% } \\
(\mathbf{2 0 1 8} / \mathbf{2 0 1 7})\end{array}$ & $\begin{array}{l}\text { Change in } \\
\mathbf{1 0 0 0} \text { persons } \\
\mathbf{( 2 0 1 8 / 2 0 0 8 )}\end{array}$ & $\begin{array}{l}\text { Change in } \\
\text { \% } \\
\mathbf{( 2 0 1 8 / 2 0 0 8 )}\end{array}$ \\
\hline Poland & 16404 & 89 & 0.5 & 672 & 4.3 \\
\hline $\begin{array}{l}\text { Makroregion } \\
\text { Południowy }\end{array}$ & 3290 & 5 & 0.1 & 158 & 5.1 \\
\hline $\begin{array}{l}\text { Makroregion } \\
\text { Pólnocno- } \\
\text { Zachodni }\end{array}$ & 2703 & 23 & 0.9 & 438 & 19.3 \\
\hline $\begin{array}{l}\text { Makroregion } \\
\text { Południowo- } \\
\text { Zachodni }\end{array}$ & 1614 & 8 & 0.5 & 107 & 7.1 \\
\hline $\begin{array}{l}\text { Makroregion } \\
\text { Pólnocny }\end{array}$ & 2417 & 12 & 0.5 & 338 & 16.2 \\
\hline $\begin{array}{l}\text { Makroregion } \\
\text { Centralny }\end{array}$ & 1639 & -2 & -0.1 & -282 & -14.7 \\
\hline $\begin{array}{l}\text { Makroregion } \\
\text { Wschodni }\end{array}$ & 2188 & 2 & 0.1 & -160 & -.6 .8 \\
\hline $\begin{array}{l}\text { Makroregion } \\
\text { Województwo } \\
\text { Mazowieckie }\end{array}$ & 2552 & 42 & 1.7 & 74 & 3.0 \\
\hline
\end{tabular}

Source: Drawn up by the authors on the basis of Eurostat (2020b).

Analyzing the data, specified in Table 2, we can draw conclusions that in general the country's employment rate increased by $0,5 \%$ in 2018 compared to 2017 . Herewith, the largest growth was observed in Makroregion Województwo Mazowieckie - by $1,7 \%$, and in Makroregion Północno-Zachodni - by 0,9\%. Along with this, the employment rate had a negative trend in Makroregion Centralny at $-0,1 \%$. At the same time, it should be noted that in the territories with the highest level of GDP, the trend was positive, but not at a high level. This trend, along with the events of the last year, indicates the need for strategic planning of employment growth to ensure sustainable development of all territories of the country. 
In addition, there is special institute responsible for territories' development in Poland - the Ministry of Regional Development. The implementation of various programs for strategic development of territories in the country is carried out under its supervision as well as under the auspices of European Union; these programs are the end product of the strategic planning process.

Thus, the following territories' development programs are in place in Poland at the time of the study:

1. Polish National Strategy of Regional Development 2010-2020: Regions, Cities, and Rural Areas for Poland (the NSRD 2010-2020 (OECD, 2020).

2. National Program for the Social Economy Development (KPRES) 2015 2020 (McNamara, 2018).

3. The Rural Development Program 2014-2020 (Eurostat, 2019).

4. Koncepcja Przestrzennego Zagospodarowania Kraju 2008-2033 (Karpenko, 2016).

5. National development strategy of Poland 2012-2020 (Karpenko, 2016).

6. Regional Development strategy of the Voivodeship until 2020 (Petrunenko et al., 2020)

A common feature of almost all these programs and strategies is the deadline for their completion, which falls at the end of 2020. Therefore, we can conclude that the results of this year will be decisive in the process of further strategic planning of territories' development, which is a positive factor, taking into account global trends of significant economic recession in all countries, including Poland. This will make it possible for competent authorities to provide appropriate support to territories where the situation will be worse compared to those territories that have shown positive dynamics of economic growth over more than one period, along with providing support to the latter in those directions that are most negatively influenced by the effects of international quarantine.

At the same time, it should be noted that the above-mentioned programs are funded from a number of sources, including EU funds, National Operational Programs, ESF, as well as public and private funds (McNamara, 2018). Significant support among all participants in financing of territories' development is provided to countries by European Regional Development Fund. During its existence, the program was implemented in the following directions with the support of the fund, as well as with the participation of its partners (Figure 3).

Consequently, from the figure presented this fund implements programs in 4 areas: Research and Innovation, SME competitiveness, Low-carbon economy and Environment and resource efficiency, the total coverage of which ranges from 60 to 67 programs. The largest number of them was focused on the environment and resource efficiency 67, and the smallest on the Low-carbon economy 60 programs, respectively (Corporative Finance Institute, n.d.). 
Figure 3. Programs of European Regional Development Fund

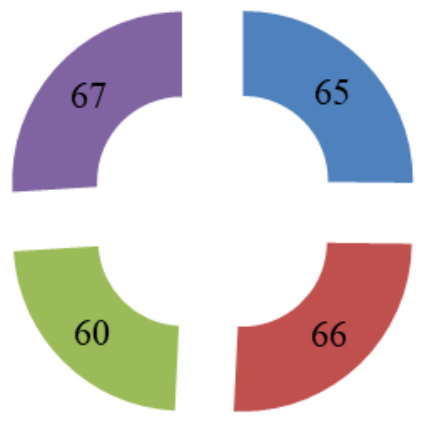

Research and Innovation

- SME competitiveness

Low-carbon economy

Environment and resource efficiency

Source: Created by the authors on Vo (2018).

\section{Discussion and Conclusions}

Based on the study conducted, it has been found that it is necessary to conduct effective strategic planning to ensure the stimulation of economic growth of the territories. Herewith, the process of its implementation is extremely complex and multi-component, which in turn requires the involvement of a large number of specialists in the process of its implementation, along with the obligation to conduct a thorough analysis in preparation for strategic planning.

However, despite the difficulties at the stage of preparation of the strategic plan, more and more countries use this tool to promote sustainable development of territories in their activities. The experience of Poland is a vivid example, which has shown positive rates of economic growth and employment over recent years, including through the implementation of territories' development programs and strategies. At the same time, taking into account the current realities, the role of strategic planning for the development of the territory reaches a fundamentally new level, and the effectiveness of its implementation depends on the rate of return of the world's economy to the pre-quarantine level.

So, the study conducted contains information about the essence of strategic planning, as well as components of the process of its implementation. In addition, the academic paper has defined the directions of its implementation, namely, that it can focus on the development of such areas, as tourism, transportation, health care, education, natural resources, business sector, infrastructure, social sphere, environment.

Along with this, it has been determined that in the context of various countries, relevant specialized institutions are formed, responsible for carrying out strategic planning for the development of territories, which they actively cooperate in this process with European institutions. An example of a supreme body at European 
Union's level is the practice of the Institute of Regional Development's functioning, the main activity of which is to promote the development of European territories, the international exchange of know-how and experience and the formation of key players in various spheres.

At the same time, when conducting strategic planning, it is extremely important to consider the initial data on the situation in the territories. The analysis of territories' GDP is a vivid example of the analysis of initial data. Among the countries considered it should be noted about the interesting experience of Poland, which in recent years has shown a steady pace of economic growth. Therefore, the academic paper has considered the level of employment in the country in the territories' context, as well as analyzed the existing programs and strategies for the development of territories, the effectiveness of which is expressed in the national economic growth of the country.

In addition, it has been determined that the role of strategic planning in ensuring the sustainable development of both territories and the country as a whole reaches a fundamentally new level, taking into account the realities, due to the fact that the negative effects of global quarantine have been felt by almost everyone and now it will be necessary to develop an effective plan to eliminate them as soon as possible.

\section{References:}

Albrechts, L., Balducci, A., Hillier, J. 2017. Situated practices of strategic planning - An international perspective. Routledge, London, UK.

Arabadzhyiev, D.Yu., Buryk, Z.M., Barshatska, H.Yu., Huba, M.I., Shashyna, M.V. 2020. Establishing interterritorial cooperation of amalgamated territorial communities as a tool to increase their capacity. International Journal of Management, 11(5), 10361044.

Bashtannyk, V., Buryk, Z., Kokhan, M., Vlasenko, T., Skryl, V. 2020. Financial, economic, and sustainable development of states within the conditions of industry 4.0. International Journal of Management, 11(4), 406-413.

Blakely, E. 1994. Planning Local Economic Development - Theory and Practice. SAGE Publications, Thousand Oaks, CA.

Brocks, S., Schulitz, A. 2006. Integrated Regional Development Concepts: A practical guide for the elaboration and implementation of Regional Development Concepts. BVLEG, Berlin, Germany.

Corporative Finance Institute. n.d. Strategic Planning? Available at: https://corporatefinanceinstitute.com/resources/knowledge/strategy/strategicplanning/.

Eurostat. 2019. Eurostat Regional Yearbook: 2019 edition. Available at: https://ec.europa.eu/eurostat/documents/3217494/10095393/KS-HA-19-001-ENN.pdf/d434affa-99cd-4ebf-a3e3-6d4a5f10bb07.

Eurostat. 2020a. Employment grew in 9 out of 10 EU regions in 2018. Available at: https://ec.europa.eu/eurostat/documents/2995521/10501993/1-05032020-BPEN.pdf/ad24c830-0394-8605-dc26-66015e815148. 
Eurostat. 2020b. Regional GDP per capita ranged from $30 \%$ to $263 \%$ of the EU average in 2018. Available at: https://ec.europa.eu/eurostat/documents/2995521/10474907/105032020-AP-EN.pdf/81807e19-e4c8-2e53-c98a-933f5bf30f58.

Interreg Europe. n.d. Approved Projects. Available at: https://www.interregeurope.eu/discover-projects/.

Jerzy, M., Ciaian, P., Di Marcantonio, F. 2019. Regional impacts of the EU Rural Development Programme: Poland's food processing sector. Regional Studies, 49, 6567.

Karpenko, A. 2016. Strategic planning as an instrument of innovative development of the region. Ekonomika, Finansy, Pravo, 5, 3-7.

Klymenko, V.V., Akimova, L.M., Korzh, M.V. 2016. Regional aspects of middle-class development in Ukraine. Actual Problems of Economics, 4(178), 178-188.

Mccarty, D. 2020. 7 Important Elements of a Strategic Plan. The Balance Careers. Available at: https://www.thebalancecareers.com/strategic-plan-elements-2276139.

McNamara, C. 2018. All about strategic planning. Free Management Library. Available at: https://managementhelp.org/strategicplanning/index.htm.

Metaxas, T. 2002. Place/City Marketing as a tool for local economic development and city's competitiveness: a comparative evaluation of Place Marketing policies in European cities. Place Marketing, Local Economic Development and City's competitiveness. Available at: http://www.china-up.com:8080/international/case/case/1075.pdf.

OECD. 2020. Regional Strategies for the Social Economy: Examples from France, Spain, Sweden, and Poland. Available at: https://www.oecdilibrary.org/docserver/76995b39-

en.pdf?expires $=1593699111 \& \mathrm{id}=\mathrm{id} \&$ accname $=$ guest $\&$ checksum $=$ BD0DC7C4615D2 9B51474E39FA0A16EA3.

Petrunenko, I., Malinoshevska, K., Kliutsa, S., Dukhnevych, A., Demianyshyna, O. 2020. Strategy, economic and legal foundations for the development of agro-industrial complex within the conditions ensuring of food security. International Journal of Management, 11(6), 463-475.

Plaziak, M., Rachwal, T. 2014. The role of entrepreneurship in regional development strategies (based on the Polish National Strategy of Regional Development 20102020). Europa XXI, 26, 97-98.

Romanenko, Y.O. 2016. Place and role of communication in public policy. Actual problems of Economics, 2 (176), 25-31.

Teixeira, D., Boda, P. 2019. Regional Development Strategies the key for local and regional governance. European Committee of the Regions. Available at: https://cor.europa.eu/en/news/Pages/Regional-Development-Strategies-the-key-forlocal-and-regional-governance.aspx.

The World Bank. 2020. The World Bank in Poland: Country Context. Available at: https://www.worldbank.org/en/country/poland/overview.

Vo, E. 2018. What is Strategic Planning? Available at: https://sba.thehartford.com/businessmanagement/what-is-strategic-planning/. 